Keywords: dialect, Eastern-Steppes dialects, Donetsk region sub-dialects, chrestomathy of dialects, transcription, dialectal texts, dialectal peculiarities.

Vitae

Nataliya Klymenko is Associate Professor of Language Training Department in Donetsk National Technical University. Her areas of research interests include Ukrainian Dialectology, lexicography, dialect textography, lexicology, semasiology, phonetics.

Correspondence: klymenko2010@gmail.com

УДК 801.313

\title{
ОЗНАКИ ДЕНОТАТА ЯК МОТИВ НОМІНАЦІЇ СПІВВІДНОСНОЇ НАЗВИ (у межах Слобожанщини)
}

У статті проаналізовано особливості формування назв природних географічних об'єктів - річок, озер, балок, улоговин, ярів, які стали твірними для ойконімних лексем. Досліджуваний матеріал згруповано за лексико-семантичними ознаками, як внутрішніми, так $і$ зовнішніми, покладеними в основу топонімної номінації, де для кожного класу вихідних топонімів існують свої принципи та способи назвотворення. Виявлено мотивувальні семи об'єкта номінаиії для кожного такого ряду.

Ключові слова: гідронім, ойконім, топонімна номінація, пейоратив, семантика.

Проблеми власних назв активно обговорюються в останні десятиліття. Вони аналізуються в різних аспектах - логічному, семіотичному, семасіологічному, соціолінгвістичному, лексикографічному та ін. (В. Д. Бондалетов, Л. А. Введенська, Т. В. Іванцова, Н. В. Подольська, О. В. Суперанская та ін.). Незважаючи на наукові твердження про наявність у власних імен значення, в конкретних ономастичних дослідженнях здійснюється розробка різних проблем ономастичної семантики: семантичних зв'язків між онімами, специфіки конотативного компонента ономастичної семантики, семантичних трансформацій при деонімізаціі та ін. Однак вивчення ономастичної лексики з погляду мотивації іï творення на основі природних ознак детально не досліджувалося. Саме цій проблемі і присвячена наша стаття.

Виявлення різних ознак, як внутрішніх, так і зовнішніх, покладених в основу топонімної номінації на рівні назв природних географічних об'єктів, становить мету нашого дослідження. Крім того, ми ставимо завдання виявити, якими конкретними ознаками стосовно природного географічного об'єкта був зумовлений вибір саме такої топонімної моделі.

Номінація на рівні ономастичного класу лексики зумовлена чинниками різного порядку і «за своєю природою є позалінгвальним явищем» [1, с. 66]. Вона безпосередньо пов'язана 3 окремими принципами топонімного творення, які близькі до такого поняття, як 'ознака, покладена в основу становлення $i$ функиіонування топоніма'.

Називаючи географічний об'єкт, номінатор цим самим індивідуалізує його та класифікує за певними властивостями, які в момент процесу найменування виділяли таку географічну одиницю серед інших природних реалій. Серед цілого комплексу першопричин називання має місце як основна властивість, так i супроводжувальні допоміжні ознаки.

Ti назви, в основі яких знаходяться географічні лексеми із розрізнювальними ознаками, мали їх у найбільшій активності саме в процесі топонімотворення. У зв'язку з цим необхідно зазначити, що в апелятивах із географічною семантикою вміщено набагато більше можливостей утворити назву поселення у зв'язку 3 абсолютною нерозповсюдженістю своїх зовнішніх властивостей.

Надаючи власну назву певному об’єктові, представники певного лінгвокультурного середовища, зазвичай , зосереджують свою увагу на їі визначальних характеристиках, оскільки ойконіми як розрізнювальні знаки самі по собі ніяких ознак відповідних об’єктів не передають. Ці характерні особливості в результаті топонімічної метонімії переносяться на населений пункт, а точніше - передається не сама ознака, а назва, мотивована нею. Наслідком такого процесу може бути «відносна негативність» [3, с. 38], яка регламентує появу ойконімних одиниць i не регламентує факту їхнього існування [2, с. 44]. Вона передбачає невідповідність ознак природних та штучних географічних одиниць. Саме́ ж контактне перенесення назви як особливість взаємодії різних видів топонімів є за своєю суттю вторинною опозицією в топонімії регіону. Найповніше в них реалізується номінаційна установка на відображення характерних рис поселення як складової частини природно-географічного середовища. У рамках топонімічної метонімії виділення населених пунктів здійснюється за зв'язком із назвою географічного об'єкта, суміжного з ним. Але природні об'єкти, на відміну від штучних, втягуються у процес номінації на основі своїх природних властивостей.

Для кожного класу вихідних топонімів існують свої принципи та способи номінації. Так, назви річок або реалії $з$ позитивним чи негативним вираженням рельєфу мотивуються переважно статичними ознаками. Для гідронімів значущим $є$ характер течії, колір та смак води, зв'язок із флорою та фауною, для оронімів - 


\section{РОЗДІЛ VІ. ЛІНГВОГЕОГРАФІЯ, СОЦІОЛІНГВІСТИКА, ОНОМАСТИКА Й ТЕРМІНОЛОГІЯ: АКТУАЛЬНІ ПІДХОДИ, КАТЕГОРІЇ ТА АСПЕКТИ}

наявність або відсутність лісового або трав'яного покриву, форма об’єкта, характер верхнього шару грунту. Тому на основі наявних властивостей мова йде про гідронімно-ойконімний, оронімно-ойконімний та мікротопонімно-ойконімний типи міжвидової трансонімізації.

Досліджуваний матеріал згруповано за лексико-семантичними ознаками, покладеними в основу топонімної номінації. При цьому враховуються характер шуму, який створює вода, швидкість течії в річці, смак та колір води, її температура, конфігурація самого об'єкта тощо:

1. Гідроніми, що відображають характер шуму, який створює співвідносний об’єкт. У цьому разі номінація відбувається на основі таких ознак:

- 'веселий' $\rightarrow$ Весела, р. $\rightarrow$ Веселий, х. [Хр Охт, АСУГ-ПАхтУ], Весела, д. [Хр Охт, ХГ СНМ, с. 27], Веселе, с. [Хр Крпл, ОХН, с. 159];

- 'гремучий' / 'грем'ячий' $\rightarrow$ Гремуча, р. $\rightarrow$ Верхня Гремуча, х. [Хр Стрб, ХГ СНМ, с. 153], Нижня Гремуча, х. [Хр Стрб, ХГ СНМ, с. 153], Гремучий Колодязь, р. $\rightarrow$ Гремучий Колодязь, х. [Кр Бгр, КГ СНМ, с. 30], Гремучий, х. [Бгр Бгр, БО АТД, с. 23], Грем'яча, б. $\rightarrow$ Грем'ячий, х. [Вр Остр, ЮЧВГ], Грем'ячий, кол. $\rightarrow$ Грем'ячий Колодязь, с. [Хр Чг, ОХН, с. 141], Грем'ячий Колодязь, х. [Хр Ввч, АСУГ-ПВлчУ];

- 'ревучий' $\rightarrow$ Реуча, р. $\rightarrow$ Реучий (Реучанський), х. [Хр Куп, ХГ СНМ, с. 111], Реучий (Реучанський), х. [Хр Куп, ХГ СНМ, с. 111], Реучий, х. [Хр Куп, СВСХГ, с. 32], Реуча, х. [Хр Св, СЗПКО, с. 54], Ревуче, с. [Хр Куп, АТП-46, с. 605];

- 'хрипіти' $\rightarrow$ Хрипуля, р. $\rightarrow$ Хрипуля, д. [Хр См, ХГ СНМ, с. 169].

Ці назви мають єдину ознаку - здатність подавати певні звуки, тобто створювати або не створювати шумові ситуації, і утворені способом уособлювальної метафори. Семема 'звук' виражається перенесенням позначення назви істоти на гідронімний об'єкт.

2. Назви первинних утворень, що реалізувалися на основі характерного смаку води.

Найчастіше, такі об’єкти відображають гіркий, солоний або кислуватий присмак води і в регіоні передаються в основному за допомогою гідронімної лексеми вовчий: Вовча, p. $\rightarrow$ Вовчий, х. [Хр Ввч, ХГ СНМ, c. 65] - Вовчанські Хутори, х. [Хр Ввч, ХГ СНМ, с. 65] - Вовча, сл. [там само] - Вовча Мала, сл. [там само, c. 66]. Для таких образних гідронімів характерна негативна оцінка, що виражається за допомогою пейоративних ономастичних лексем. Ці назви виникли на грунті образного народного бачення. Вони надаються тим природним об'єктам, які викликають негативні емоції у суб'єктів і позбавлені етимологічного та смислового зв'язку з апелятивом вовк, бірюк і негативно характеризують географічні об'єкти, які не мають у житті людини господарського значення [4, с. 23; 5, с. 115]. Отже, в подібних топонімних утвореннях виявлено пейоративну семантику, що підтверджується наявністю в регіоні назв, які прямо характеризують ГО: Солоний, д. [Хр Куп, СВСХГ, с. 31], Солоний, х. [Хр Куп, СКХЕ, с. 315], Солона (Верхня Солона), д. [Хр Куп, ХГ СНМ, c. 116], Вища Солона, сл. [Хр Куп, ХГ СНМ, с. 116], Селище Солоне [Хр Куп, ССОВХГ, с. 87] (всі співвідносні об'єкти цих назв локалізуються при річці Солоній). Отже, негативна семантика пейоративної лексики «народжується при уподібненні одного предмета іншому на основі подібних негативних ознак, при метафоричному переносі» [6, с. 81]. Але не всі назви т. зв. «вовчого» або «бірючого» походження слід вважати пейоративними (метафоричними). Найбільшу вірогідність вони мають у безпосередній близькості від річки Вовчої (вар. Вовчі Води, р.), де діє явище трансонімізації за моделлю «гідронім $\rightarrow$ ойконім». У місцях більш віддаленого розташування подібна інтерпретація може виявитися неправильною. Особливо це яскраво виявляється в назві поселення, що знаходяться недалеко одне від одного і становлять корелятивні пари за відповідним принципом семантичного зв'язку (пор.: Вовчий Яр, с. [Дц Крлм, АТУ-87, с. 77] - Коровій Яр, с. [там само], що є традиційним для східнослов'янської ойоконімії. Можливо, що до цієї групи топонімів належать і назви, в основу яких було покладено іменник свиня та прикметник вщивий: Свинуха, р. $\rightarrow$ Мєловатська Свинуха, сл. [Вр Остр, ВГ СНМ, с. 124], Свинюха, р. $\rightarrow$ Свинюха, х. [Вр Бгч, НМВГ-28, с. 24], Виива, р. $\rightarrow$ Виива, сл. [Вр Вал, ВГ СНМ, с. 66].

3. Топоніми, що відображають колір води або грунту.

У цьому разі мотивувальними виступають такі семи об’єкта номінації, як:

- 'білий' $\rightarrow$ Біла, р. $\rightarrow$ Біла, сл. [Хр Стрб, КСУГ-РА], Біле, с. [Хр Куп, ТКХО], Біленька, р. $\rightarrow$ Білий Колодязь, х. [Кр Носк, КГ СНМ, с. 81], Білий Колодязь, р. $\rightarrow$ Білий Колодязь, х. [Хр Стрб, ХГ СНМ, с. 151], Білий, кол. $\rightarrow$ Білий Колодязь, сц. [Кр Сдж, КГ СНМ, с. 132];

- 'бурий’ $\rightarrow$ Буре, ур. $\rightarrow$ Бурий, х. [Хр Влк, ХГ СНМ, с. 44];

- 'грязний' (укр. 'брудний') $\rightarrow$ Грязна, р. $\rightarrow$ Грязна, д. [Хр Охт, ХГ СНМ, с. 29], Грязна Потудань, p. $\rightarrow$ Грязний Потудань (Грязна Потудань), сл. [Вр Кртк, ВГ СНМ, с. 96];

- 'іржавий' $\rightarrow$ Ржавка, р. $\rightarrow$ Ржавка, с. [Кр Сдж, КГ СНМ, с. 132], Ржавець, став $\rightarrow$ Ржавецьь, д. [Хр Хр, ХГ СНМ, с. 11], Ржавець, р. $\rightarrow$ Ржавець, сл. [Хр Хр, ОХН, с. 137], Ржави, сл. [Хр Хр, ОИКСОМГ, с. 550];

- 'красний' $\rightarrow$ Красна, р. $\rightarrow$ Красна, сл. [Хр Куп, ХГ СНМ, с. 120], Ново-Красна, сл. [Хр Куп, ХГ СНМ, с. 128], Красна, сл. [Хр Стрб, ХГ СНМ, с. 147];

- 'рудий' $\rightarrow$ Рудий Байрак, ур. $\rightarrow$ Рудий Байрак, х. [Хр Влк, ХГ СНМ, с. 46], Рудий Байрак, с. [Хр Влк, АТП-67, с. 413];

- 'сизий' $\rightarrow$ Сизе, оз. $\rightarrow$ Сизе, с. [Лг Стлг, АТП-67, с. 253]; 
- ' 'синій’ $\rightarrow$ Синій Колодязь, р. $\rightarrow$ Синій Колодязь, х. [Кр Крч, КГ СНМ, с. 62], Синій Колодязь, руч. $\rightarrow$ Синій Колодязь Другий, х. [Кр Крч, КГ СНМ, с. 63];

- 'сірий’ $\rightarrow$ Сірий Яр, б. $\rightarrow$ Сірий Яр, х. [Хр Ввч, КВУ], Сірий Яр, ур. $\rightarrow$ Сірий Яр, с. [Хр Вбрл, ТКХО]; ЮЧВГ];

- 'срібний’ $\rightarrow$ Серебрянка, p. $\rightarrow$ Серебрянка, сл. [Кр Носк, КГ СНМ, с. 76], Серебрянський, х. [Вр Остр,

- 'чорний' $\rightarrow$ Чорна, р. $\rightarrow$ Верхній Чорнявський [Вр Остр, ЮЧВГ], Середній Чорнявський [Вр Остр, ЮЧВГ], Нижній Чорнявський [Вр Остр, ЮЧВГ].

4. Топоніми із відображенням запаху води.

Домінувальною буде така властивість географічної реалеми, як 'гнилий' $\rightarrow$ Гнилиия, р. $\rightarrow$ Гнилиия, д. [Хр Ввч, ХГ СНМ, с. 64], Гнилиия, р. $\rightarrow$ Гнилиця, с. [Хр Зм, ХГ СНМ, с. 80], Гнила, р. $\rightarrow$ Гнила, сл. [Хр Куп, ХГ СНМ, с. 128], Гнилуша, прот. руч. $\rightarrow$ Гнилуша, с. [Вр Вал, ВГ СНМ, с. 131], Гнила Вериина, р. $\rightarrow$ Гнила, сл. [Хр Куп, Р. ПГОНО, с. 261] та ін. Ймовірно, що до цієї лексико-семантичної групи належить також пейоратив із значенням 'псиний' (Псинка, р. $\rightarrow$ Псинка, с. [Кр Об, КГ СНМ, с. 86] $\rightarrow$ Мала Псинка, д. [там само] $\rightarrow$ Псинський, х. [там само, с. 87]) та 'свинячий’ (Свиняча, яруга $\rightarrow$ Свиняча Яруга, х. [Кр Крч, КГ СНМ, с. 60], Свинуха, р. $\rightarrow$ Меловатська Свинуха, сл. [Вр Остр, ВГ СНМ, с. 124]).

5. Гідроніми, що відображають швидкість течії води.

Ця група включає такі назви, як Скакун, p. $\rightarrow$ Скакун, д. [Вр Змл, ВГ СНМ. с. 82] (від первинного апелятива скакун), Бистрик, яр $\rightarrow$ Бистрик, х. [Хр Мрф, СЗПСТХО, с. 58], Бистрий, х. [Хр Хр, СКХЕ, с. 84] (від лексеми бистрий), Рєзвий Колодязь, р. $\rightarrow$ Верхів'я-Рєзвий-Колодязь, сц. [Вр Змл, ВГ СНМ, с. 81] $\rightarrow$ Рєзвий Колодязь, д. [там само] (від лексеми рєзвий). Семи 'тихий' та 'в'ялий', втілені в ряді таких найменувань, як В'яла, p. $\rightarrow$ В'ялий, х. [Хр Хр, АХН-КХрУ], В'яле, с. [Хр Хр, ХО. АТП-67, 44], В'яле, х. [Хр Лпц, АТП-46, c. 606] та Дон, р. $\rightarrow$ Тихий Дон, х. [Вр Бгч, АТД-59, с. 28], де в останньому прикладі саме через ойконім передається властивість річкового об’єкта.

Поява вихідних топонімів зумовлена впливом моделі «уособлювальна метафора», де найсильніше проявляється дія екстралінгвального чинника - психологія людського сприйняття. Тому все, що може рухатися і переміщуватися, перебуває в динаміці - порівнюється з істотою.

6. Топоніми, що мають властивість 'структура трунту', 'характер берегової лінії або річкового дна'. Визначальними є такі семи, як:

- 'әлиняний' $\rightarrow$ Глинка, р. $\rightarrow$ Глинськ, с. [Плт Знк, ПГ СНМ, с. 54];

- 'кам'яний' $\rightarrow$ Кам'яний, яр $\rightarrow$ Кам'яний [Хр Зм, ИСОХЕ-4, с. 78], Кам'яна, с. [Хр Стрб, КСУГ-РА], Кам'яне (Кам'яна), с. [Хр Стрб, ХГ СНМ, с. 159], Кам'яна Яруга, с. [Хр Зм, ХГ СНМ, с. 79], Кам'янка, р. $\rightarrow$ Кам'янка х. [Хр Стрб, ХГ СНМ, с. 149], Кам'яний, кол. $\rightarrow$ Кам'яний Колодязь, х. [Хр Стрб, СВСХГ, с. 38];

- 'крейдяний' $\rightarrow$ Крейдяний, яр $\rightarrow$ Крейдяне, с. [Врш Блвд, АТП-72, с. 62], Крейдяний, х. [Врш Мрк, АТП-46, с. 92], Крейдяне, с. [Лг Мрк, АТП-67, с. 249];

- 'кремінний' $\rightarrow$ Кремінний, руч. $\rightarrow$ Кремінна, м. [Врш Крм, АТП-46, с. 89], Кремінна, сл. [Хр Куп, ИСОХЕ-5, с. 299], Кремінна, с. [Хр Кб, ПИПН, с. 29], Кремінна, х. [Слб. Укр. губ. (Куп), ПКРИ, с. 61];

- 'міловий' $\rightarrow$ Мілова, р. $\rightarrow$ Мілова, сл. [Хр Із, ХГ СНМ, с. 77], Мілова, с. [Хр Зм, СКХЕ, с. 242], Мілова, х. [Хр Хр, ХУ-КС], Мілове, с. [Хр Блк, АТП-67, с. 409], Мілове, смт [Врш Млв, АТП-46, с. 92];

- 'піщаний' / 'пісочний' $\rightarrow$ Пісочна, p. $\rightarrow$ Пісочин, сл. [Хр Хр, ОХН, с. 137], Пісочин, с. [Хр Хр, ОИКСОМГ, с. 550], Піщзана, р. $\rightarrow$ Піщзаний, х. [Хр Куп, ХГ СНМ, с. 110], Пішаний (Пішана), х. [Хр Куп, ХГ СНМ, с. 114], Пішуана, сл. [Хр Куп, СВСХГ, с. 32], Піщзана, х. [Хр Куп, АТП-46, с. 605], Пішана, с. [Хр Куп, АТП-46, с. 605];

- 'розсипний' $\rightarrow$ Розсипна, б. $\rightarrow$ Розсипне, с. [Вр Клч, с. ВВ3, 270].

7. Гідроніми із зазначенням температури води. Тут перевага віддається семантичному типу 'студений' та протилежному за значенням 'теплий': Студенок, р. $\rightarrow$ Студенок, х. [Хр Хр, ХГ СНМ, с. 12], Студенок, с. [Хр Із, ИСОХЕ-5, с. 65], Студенець, р. $\rightarrow$ Студенець, х. [Хр Стрб, СКХЕ, с. 408], Стууденцьк, д. [Хр Стрб, СВСХГ, с. 41], Студенеиький, х. [Хр Стрб, ХГ СНМ, с. 148], Студенеиький, д. [Хр Стрб, ХГ СНМ, с. 148], Студенок, прот. $\rightarrow$ Студенок (Студенеиьь), х. [Вр Бгч, ВГ СНМ, с. 49], Студений Колодязь, р. $\rightarrow$ Студений Колодязь, х. [Вр Брч, ВГ СНМ, с. 27], Студений Колодязь, сл. [Хр Чг, ОХН, с. 80]; Тепла, р. $\rightarrow$ Верхньотеплий, х. [Лг Стлг, СНПЛО, с. 116], Середньотеплий, х. [Лг Стлг, СНПЛО, с. 116], Тепле, с. [Лг Стлг, АТП-67, с. 254], Нижньо-Тепле, с. [Врш Вртп, АТП-46, с. 86].

8. Топоніми із «флористичною» семантикою, які вказують на наявність чи відсутність елементів рослинного світу. Визначальними є такі ознаки, як:

- 'береза' $\rightarrow$ Березнягівський, яр $\rightarrow$ Березняги (Берізки), х. [Вр Остр, ВГ СНМ, с. 118], Березняги, х. [Вр Рзш, НМВГ-28, с. 118], Березова, р. $\rightarrow$ Березівський, х. [Хр Куп, ХГ СНМ, с. 113], Березове, оз. $\rightarrow$ Березівка (Березова), сл. [Вр Бгч, ВГ СНМ, с. 53];

- 'берека' $\rightarrow$ Берека, р. $\rightarrow$ Берека, сл. [Хр Зм, ИСОХЕ-4, с. 253], Берека (Верхоберека), сл. [Хр Зм, Р. ПГОНО, с. 273], Берека, х. [Хр Зм, СВСХГ, с. 18], Берека, д. [Хр Зм, ХГ СНМ, с. 75];

- 'берест' $\rightarrow$ Берестова, p. $\rightarrow$ Берестовий, х. [Хр Зм, ХГ СНМ, с. 84], Берестовий (Берестова), х. [Хр Куп, ХГ СНМ, с. 115], Берестова, х. [Хр Зм, СВСХГ, с. 16], Берестова, с. [Хр Куп, АТП-46, с. 604], Берестове, c. [Хр Куп, СКХЕ, с. 320]; 


\section{РОЗДІЛ VІ. ЛІНГВОГЕОГРАФІЯ, СОЦІОЛІНГВІСТИКА, ОНОМАСТИКА Й ТЕРМІНОЛОГІЯ: АКТУАЛЬНІ ПІДХОДИ, КАТЕГОРІЇ ТА АСПЕКТИ}

- 'бір’ $\rightarrow$ Борова, р. $\rightarrow$ Боровий, х. [Хр Куп, СКХЕ, с. 342], Борова, сл. [Хр Куп, Р. ПГОНО, с. 260], Борівська, д. [Хр Куп, ХГ СНМ, с. 111], Боровенька, сл. [Хр Стрб, ХГ СНМ, с. 158], Борове, оз. $\rightarrow$ Борова, д. [Хр Стрб, ХГ СНМ, с. 160];

- 'в'язь' $\rightarrow$ В'язова, р. $\rightarrow$ В'язове, с. [Кр Грв, КГ СНМ, с. 33], В'язове, ур. $\rightarrow$ В'язовий, х. [Вр Бгч, ВГ СНМ, с. 52], В'язовий, яр $\rightarrow$ В'язове, с. [Хр Дрг, ХО. АТП-59, с. 21], В'язовий, х. [Хр Дрг, АТП-46, с. 598];

- 'вишня' $\rightarrow$ Вишнева, р. $\rightarrow$ Вишневий, х. [Хр Влк, ХГ СНМ, с. 47], Вишневе, с. [Хр Влк, АТУ-87, с. 274];

- 'вільха' $\rightarrow$ Вільхова, р. $\rightarrow$ Вільхове, сел. [Врш Стлг, АТП-46, с. 101], Вільхуватка, р. $\rightarrow$ Вільхуватка, сл. [Вр Остр, ВГ СНМ, с. 124], Вільхуватка, с. [Вр Рзш, НМВГ-28, с. 108], Вільшана, р. $\rightarrow$ Вільшана, сл. [Хр Куп, Р. ПГОНО, с. 260], Вільшана, с. [Хр Дврч, ХО. АТП-59, с. 19], Вільшана, сл. [Хр Лбд, Р. ПГОНО, с. 432], Вільшана, д. [Хр Лбд, ХГ СНМ, с. 133]; CHM, c. 16];

- 'горіх' $\rightarrow$ Горіхова, верш. ур. $\rightarrow$ Горішанка, д. [Хр Хр, ХГ СНМ, с. 16], Горішинський, х. [Хр Хр, ХГ

- 'горох' $\rightarrow$ Горохуватка, р. $\rightarrow$ Горохуватка, сл. [Хр Куп, ХГ СНМ, с. 111], Горохуватка, с. [Хр Бр, ХО. АТП-71, с. 21];

- 'груша' $\rightarrow$ Грушовий, яр $\rightarrow$ Грушовий, х. [Вр Бгч, СССВГ. БгчУ, с. 4], Грушова, сл. [Вр Бгч, НМВГ28, с. 24], Грушуваха, р. $\rightarrow$ Грушуваха, сл. [Хр Із, АСУГ-ПИзУ];

- 'дуб’ $\rightarrow$ Дубова, б. $\rightarrow$ Дубівка, с. [Хр Дрг, АТП-67, с. 418], Дубове, с. [Хр Блз, АТП-67, с. 411], Дубовий, яр $\rightarrow$ Дубовенька, с. [Бгр Шбк, ТКХБО], Дубовецьь, яр $\rightarrow$ Дубовівка, х. [Врш Стрб, АТП-46, с. 102], Дубовівка, с. [Лг Стрб, АТП-67, с. 254];

- 'іва' $\rightarrow$ Івинка, р. $\rightarrow$ Івенка, х. [Кр Грв, КГ СНМ, с. 39], Івиия, р. $\rightarrow$ Івиия, сл. [Кр Крч, КГ СНМ, с. 56], Івня, д. [Кр Грв, КГ СНМ, с. 37], Ів'янка, д. [Кр Грв, СССКГ. ГУ, с. 2, с. 174], Івня, р. $\rightarrow$ Івня, д. [Хр Хтм, ОХН-КХтмУ];

- 'калина' $\rightarrow$ Калинова Балка, яр $\rightarrow$ Калинова Балка, х. [Хр Стрб, ХГ СНМ, с. 147], Калинова Балка, с. [Врш Лзол, АТП-46, с. 91];

- 'ковила' $\rightarrow$ Ковильна, улог. $\rightarrow$ Ковильний, х. [Вр Бгч, АТД-59, с. 27], Ковильний (Ковильна), х. [Вр Пвл, СССВГ. ПУ, с. 6], Ковильня, х. [Вр Бгч, НМВГ-28, с. 27];

- 'комиш' $\rightarrow$ Комишна, р. $\rightarrow$ Комишна, с. [Кр Сдж, КГ СНМ, с. 136], Комишне, с. [Врш Стлг, АТП-46, с. 101], Комишна, сл. [Хр Стрб, ЖТКХГ, с. 625], Комишуваха, р. $\rightarrow$ Комишуваха, сл. [Хр Влк, Р. ПГОНО, с. 290];

- 'конопля' $\rightarrow$ Конопелька, p. $\rightarrow$ Конопелка, с. [Кр Сдж, ОИКСОМГ, с. 552], Руська Конопелька, д. [Кр Сдж, КГ СНМ, с. 131], Черкаська Конопелька, с. [там само], Мала Конопелька, д. [там само];

- 'липа' $\rightarrow$ Липова, б. $\rightarrow$ Липове, с. [Врш Мрк, АТП-72, с. 66], Липчанка, р. $\rightarrow$ Липціi, с. [Хр Хр, ІМСУ ХО, с. 879], Липчик, р. $\rightarrow$ Липець, м. [Хр Хр, ОИКСОМГ, с. 550], Липчик, с. [Хр Хр, ОХН, с. 96, с. 97, с. 138, с. 139], Липчик, сл. [Хр Хр, ИСОХГ, с. 126], Липиіi, сл. [Хр Хр, ХГ СНМ, с. 20];

- 'лоза' $\rightarrow$ Лозовий, яр $\rightarrow$ Лозовенька, сл. [Хр Зм, ХГ СНМ, с. 77], Лозова, р. $\rightarrow$ Лозовий Великий, х. [Хр Куп, ХГ СНМ, с. 110], Лозова, р. $\rightarrow$ Лозовий (Лозова), х. [Хр Куп, ХГ СНМ, с. 109], Лозна, р. $\rightarrow$ Лізна (Лізнянка), сл. [Вр Остр, ВГ СНМ, с. 126];

- 'малина' $\rightarrow$ Малинів, кол. $\rightarrow$ Малинівка, сл. [Хр Із, ОИКСОМГ, с. 553], Малинівка, с. [Хр Чг, ИСОХЕ-4, с. 89], Малинівка, х. [Хр Із, СКХЕ, с. 280], Малинівка, р. $\rightarrow$ Малинове, с. [Хр Зм, ХГ СНМ, с. 79], Малинівка, х. [Слб. Із. п., КСП : ХС-9], Малинівка, с. [Хр Зм, СВСХГ, с. 17];

- 'нефорощ' $\rightarrow$ Нефорощанка, б. $\rightarrow$ Нефорощанка, д. [Плт Кнгр, ПГ СНМ, с. 106], Нефорощанка, p. $\rightarrow$ Нефорощца, м-ко [Плт Кнгр, ПГ СНМ, с. 106], Нехворощ̧а, с. [Хр Схн, АТП-67, с. 427], Нехворощ̧а, х. [Хр Схн, АТП-46, с. 612];

- 'осика' $\rightarrow$ Осички, ур. $\rightarrow$ Осички, х. [Вр Остр, ВГ СНМ, с. 126], Осинова, р. $\rightarrow$ Осиновий, х. [Хр Куп, АТП-46, с. 605], Осинова, х. [Хр Куп, СКХЕ, с. 311], Осиковий, руч. $\rightarrow$ Осиківка, х. [Вр Бгч, ВГ СНМ, с. 49];

- 'очерет' $\rightarrow$ Очеретянка, р. $\rightarrow$ Очеретянка, х. [Хр Хр, ХГ СНМ, с. 19], Очеретувата, p. $\rightarrow$ Очеретівський, х. [Хр Влк, ХГ СНМ, с. 48], Очеретове, с. [Хр Влк, АТП-67, с. 414], Очеретувата, д. [Хр Із, АСУГ-ПИзУ], Очеретянка, б. $\rightarrow$ Очеретова, д. [Плт Кнгр, ПГ СНМ, с. 100], Очеретяна, д. [Плт Кнгр, ПГ CHM, c. 103];

- 'просо' $\rightarrow$ Просяна, криниця $\rightarrow$ Просяна, сл. [Хр Стрб, ХГ СНМ, с. 152], Просяне, ур. $\rightarrow$ Просяна, д. [Хр Влк, Р. ПГОНО, с. 184, с. 271], Просяне, с. [Хр Влк, ПКХГ, с. 117], Просянка, р. $\rightarrow$ Просянка (Просяна), сл. [Хр Ввч, ХГ СНМ, с. 69], Просяний, х. [Хр Ввч, СКХЕ, с. 220];

- 'рогоза' $\rightarrow$ Рогізна, р. $\rightarrow$ Рогізний, д. [Хр См, ХГ СНМ, с. 171], Рогізне, сел. [См См, АТП-67, с. 383], Рогізне, с. [См Блпл, АТП-67, с. 367], Рогозня, р. $\rightarrow$ Рогозний, х. [Хр См, ОХН, с. 152], Рогозне, с. [Хр См, $\mathrm{OXH}$, c. 152];

- 'рокита' $\rightarrow$ Ракитна, р. $\rightarrow$ Рокитна, сл. [Хр Влк, ОХН, с. 104], Ракитна, сл. [Хр Бгр, ОХН, с. 147, c. 148], Ракитна, с. [Хр Хтм, ОХН, с. 163], Рокитна, р. $\rightarrow$ Рокитна, сл. [Хр Зм, ХГ СНМ, с. 75], Рокитна, с. [Хр Влк, ОИКСОМГ, с. 551], Рокитне, с. [Хр Нвдл, ХО. АТП-59, с. 34];

- 'смородина' $\rightarrow$ Смородине, ур. $\rightarrow$ Смородин, х. [Хр Охт, ХГ СНМ, с. 30], Смородине, х. [Хр Охт, СКХЕ, с. 134], Смородине, с. [См Трс, АТП-46, с. 544], Смородина, р. $\rightarrow$ Смородина, с. [Кр Грв, КГ СНМ, c. 32], Смородине, с. [Хр Хтм, ОХН, с. 163]; 
- 'сосна' $\rightarrow$ Соснове, ур. $\rightarrow$ Соснів Ріг, х. [Хр Влк, ХГ СНМ, с. 46], Сосновий Ріг, х. [Хр Влк, СКХЕ, с. 171], Соснівка, с. [Хр Влк, АТП-67, с. 414], Сосонка, p. $\rightarrow$ Сосонка, д. [Хр Охт, ХГ СНМ, с. 24], Сосонка, c. [См Охт, АТП-67, с. 378];

- 'таволга' $\rightarrow$ Тавільжанка, p. $\rightarrow$ Тавільжанка, с. [Хр Дврч, АТП-46, с. 597], Тавільжанка, х. [Хр Куп, ХГ СНМ, с. 124], Стара Тавільжанка, с. [Бгр Шбк, БО АТД, с. 106], Нова Тавільжанка, с. [Бгр Шбк, БО АТД, c. 105];

- 'терен' $\rightarrow$ Терни, сл. [Хр Лбд, ХГ СНМ, с. 144], Терни, с. [Хр Лбд, СВСХГ, с. 36], Терни, х. [Хр Лбд, СКХЕ, с. 370], Терновий, яр $\rightarrow$ Тернова, сл. [Хр Ввч, АСУГ-ПВлчУ], Тернова, с. [Хр Ввч, АТП-46, с. 596];

- 'хвощ' $\rightarrow$ Хвощувата, б. $\rightarrow$ Хвощуватий, х. [Вр Бгч, НМВГ-28, с. 28], Фошуватий, х. [Вр Бгч, ОИКСОМГ, с. 553], Фомуватий (Хвомуватий), х. [Вр Бгч, ВГ СНМ, с. 53], Фомуватка, сл. [Вр Бгч, СССВГ. БгчУ, с. 4], Хвошуватий, яр $\rightarrow$ Фошувате, с. [Бгр Крч, ТКХБО], Фошувата, сл. [Кр Крч, КГ СНМ, с. 56], Хвошувате, сл. [Кр Крч, КГ СНМ, с. 56];

- 'хміль' $\rightarrow$ Хмельова, улог. $\rightarrow$ Хмельове, с. [Кр Крч, КГ СНМ, с. 59], Хмельовий, руч. $\rightarrow$ Хмельовий, х. [Вр Вал, НМВГ-28, с. 39], Хмельовецьь, с. [Вр Брч, ВГ СНМ, с. 28].

9. Топоніми, що відображають особливості конфігурації об'єкта.

Основними будуть такі ознаки географічної одиниці, як:

- 'гвинтоподібний' / 'зигзагоподібний’ $\rightarrow$ Коловерть, р. $\rightarrow$ Коловерть, сл-ка [Вр Остр, ВГ СНМ, с. 119];

- ‘заокруглений' $\rightarrow$ Хомуток, оз. $\rightarrow$ Хомуток, х. [Хр Зм, ХГ СНМ, с. 82];

- 'зігнутий' $\rightarrow$ Крюк, р. $\rightarrow$ Крюк, х. [Бгр Носк, БО АТД, с. 70];

- 'кривий' $\rightarrow$ Кривуша, р. $\rightarrow$ Кривуша, сл. [Вр Бгч, ОИКСОМГ, с. 554], Стара Кривуша, сл. [Вр Бгч, ВГ СНМ, с. 151], Нова Кривуша, сл. [Вр Бгч, ВГ СНМ, с. 152], Новотройиька Кривуша, сл. [Вр Бгч, ВГ СНМ, c. 154];

- 'круглий’ $\rightarrow$ Кругле, оз. $\rightarrow$ Кругле Озеро, х. [Плт Гдц, АТП-46, с. 398], Круглий, яр $\rightarrow$ Кругле, с. [Врш Св, АТП-72, с. 69], Калач, ур. $\rightarrow$ Калач, м. [Вр Остр, НМВГ-28, с. 99];

- 'розгалужений' $\rightarrow$ Розсош, р. $\rightarrow$ Розсош, сл. [Вр Вал, ВГ СНМ, с. 63, с. 64], Розсохувате, ур. $\rightarrow$ Розсохуватий, х. [Вр Бгч, ВГ СНМ, с. 47], Розсохувата, р. $\rightarrow$ Розсохувате, Д. [Хр І3, ХГ СНМ, с. 94], Розсохуватий, х. [Хр Свн, АТП-46, с. 611], Розсохувате, с. [Хр Із, АТП-67, с. 421];

- 'хрестоподібний' $\rightarrow$ Хрещчатий, яр $\rightarrow$ Хрещатий (Хрещчатик), х. [Вр Бгч, ВГ СНМ, с. 45], Хрещุатий, верш. яру $\rightarrow$ Хрищатий (Хрещатий,) х. [Вр Брч, ВГ СНМ, с. 24], Хрещзатий, х. [Бгр Мик, БО АТД, с. 67].

10. Топоніми із зазначенням геофізичних параметрів природного об'єкта, де визначальними є такі ознаки:

- 'високий' $\rightarrow$ Висока Яруга, б. $\rightarrow$ Висока Яруга, с. [Хр Дрг, ХО. АТП-59, с. 22], Високе, ур. $\rightarrow$ Високий, х. [Вр Остр, ВГ СНМ, с. 117], Високий, яр $\rightarrow$ Високий, х. [Кр Грв, КГ СНМ, с. 41], Високі Байраки, верш. $\rightarrow$ Високий Байрак, х. [Вр Остр, ВГ СНМ, с. 120];

- 'глибокий' $\rightarrow$ Глибока Долина, р. $\rightarrow$ Глибока Долина, х. [Хр Зм, СВСХГ, с. 15], Глибока Макатиха, p. $\rightarrow$ Глибока Макатиха, х. [Дц Сл, СНПАО, с. 41], Глибоке, оз. $\rightarrow$ Глибоке, с. [Вр Пп, ВВ3, с. 79], Глибокий, яр $\rightarrow$ Глибокий, х. [Вр Брч, ВГ СНМ, с. 25];

- 'довгий' $\rightarrow$ Довгий, яр $\rightarrow$ Довжик, х. [Вр Остр, ВГ СНМ, с. 119], Довжик, яр $\rightarrow$ Довжик, х. [Вр Пдгр, АТД-59, с. 90];

- 'крутий’ $\rightarrow$ Крута, б. $\rightarrow$ Крута Балка, с. [Плт Кнгр, ПГ СНМ, с. 107], Крутенький, яр $\rightarrow$ Крутий, х. [Врш Стрб, АТП-46, с. 102], Круте, с. [Лг Стрб, АТП-67, с. 254], Крутенький, х. [Врш Стрб, АТП-46, с. 102], Крутещь, верш. $\rightarrow$ Крутець, х. [Вр Остр, ВГ СНМ, с. 116];

- 'куций' $\rightarrow$ Куйа, б. $\rightarrow$ Куйа, д. [Плт Кнгр, ПГ СНМ, с. 103], Куйа Балка, х. [Плт Кнгр, ПГ СНМ, с. 103];

- 'мілкий' $\rightarrow$ Мілка Макатиха, р. $\rightarrow$ Мілка Макатиха, х. [Дц Сл, СНПАО, с. 41];

- 'низький' $\rightarrow$ Низький, яр $\rightarrow$ Низенький, х. [Кр Грв, КГ СНМ, с. 40];

- 'чиирокий' $\rightarrow$ Широка, б. $\rightarrow$ Широкий, сел. [Лг Стлг, АТП-67, с. 254].

11. Топоніми, в яких відобразилися ознаки, пов'язані із навколишньою фауною. Характерними є семи:

- 'битюг' $\rightarrow$ Битюг, р. $\rightarrow$ Битюг, х. [Вр Пдгр, АТД-59, с. 89];

- 'бичок' $\rightarrow$ Бичок, р. $\rightarrow$ Бичок, сл. [Вр Бгч, ВГ СНМ, с. 49];

- 'білка' $\rightarrow$ Білка, р. $\rightarrow$ Білка, сл. [Хр Охт, ИСОХЕ-3, с. 118];

- ‘бірюк' $\rightarrow$ Бірючка, р. $\rightarrow$ Бірюч, м. [Вр Брч, ВГ СНМ, с. 1], Бірючка, улог. $\rightarrow$ Бірючківська, сл. [Вр Брч, ВГ СНМ, с. 28];

- ‘бобер’ $\rightarrow$ Бобрик, p. $\rightarrow$ Бобрик (Великий Бобрик), с. [Хр См, ИСОХЕ-3, с. 373], Бобрик, p. $\rightarrow$ Бобрик,

д. [Хр См, ИСОХЕ-3, с. 373];

- 'вепр' $\rightarrow$ Веприк, p. $\rightarrow$ Веприк, м-ко [Плт Гдц, ПГ СНМ, с. 24];

- 'гадюка' $\rightarrow$ Гадюкова, улог. $\rightarrow$ Гадюча, сл. [Вр Бгч, ВГ СНМ, с. 50];

- 'гайворон' $\rightarrow$ Грайворонка, р. $\rightarrow$ Грайворонка, сл. [Кр Грв, КГ СНМ, с. 31];

- 'гуска' $\rightarrow$ Гусочка, р. $\rightarrow$ Гусинський (Гусочкин), х. [Хр Куп, ХГ СНМ, с. 114];

- 'жеребець ’ $\rightarrow$ Жеребецьь, p. $\rightarrow$ Жеребеиькі (Жеребець), х. [Хр Куп, ХГ СНМ, с. 108];

- 'журавель' $\rightarrow$ Журавка, р. $\rightarrow$ Журавка, сл. [Хр Стрб, ХГ СНМ, с. 254], Журавка, р. $\rightarrow$ Журавка (Журавський), х. [Хр Куп, ХГ СНМ, с. 120];

- 'кабан' $\rightarrow$ Кабаній, брід $\rightarrow$ Кабання, сл. [Хр Куп, ИСОХЕ-5, с. 309]; 


\section{РОЗДІЛ VІ. ЛІНГВОГЕОГРАФІЯ, СОЦІОЛІНГВІСТИКА, ОНОМАСТИКА Й ТЕРМІНОЛОГІЯ: АКТУАЛЬНІ ПІДХОДИ, КАТЕГОРІЇ ТА АСПЕКТИ}

- 'кобила' $\rightarrow$ Кобилка, р. $\rightarrow$ Кобильський, х. [Слб. Укр. губ. (Куп), ПКРИ, с. 60];

- 'коза' $\rightarrow$ Козинка, р. $\rightarrow$ Козинка, х. [Хр Стрб, ХГ СНМ, с. 146, с. 151];

- 'корова' $\rightarrow$ Корова, р. $\rightarrow$ Корова (Коровина), д. [Кр Грв, КГ СНМ, с. 32];

- 'куниия' $\rightarrow$ Кунья, р. $\rightarrow$ Куньє, сел. [Хр Із, ПКХГ, с. 181], Куньє, с. [Хр І3, СКХЕ, с. 267];

- 'лебідь' $\rightarrow$ Леб'яжа, p. $\rightarrow$ Леб'яже. с. [Хр Чг, ОХН, с. 141], Леб'яже, оз. $\rightarrow$ Леб'яже, с. [Хр Зм, ИСОХЕ-4, с. 264];

- 'лисиия' $\rightarrow$ Лисиия, p. $\rightarrow$ Лисиия, с. [Хр Хтм, ОХН, с. 163], Козача Лисиия, сл. [Кр Бгр, КГ СНМ, c. 32], Руська Лисиия, с. [Кр Бгр, КГ СНМ, с. 35];

- 'лошак' $\rightarrow$ Лошак, р. $\rightarrow$ Лошаківка, д. [Кр Сдж, КГ СНМ, с. 137];

- 'медвідь' $\rightarrow$ Медвежий, яр $\rightarrow$ Медвежа, сл. [Вр Бгч, СССВГ. БгчУ, с. 4], Медвеже, ур. $\rightarrow$ Медвежий, х. [Хр Влк, ХГ СНМ, с. 47];

- 'олень' $\rightarrow$ Оленій Колодязь, р. $\rightarrow$ Олень-Колодязь, с. [Вр Кртк, ВГ СНМ, с. 92];

- 'перепелиия' $\rightarrow$ Перепелицине, ур. $\rightarrow$ Перепелицин, х. [Хр Влк, ХГ СНМ, с. 46], Перепелищівка, с. [Хр Влк, АТП-67, с. 413];

- 'свиня' $\rightarrow$ Свиняча, яруга $\rightarrow$ Свиняча Яруга, х. [Кр Крч, КГ СНМ, с. 60]; c. 616].

- 'щеня' $\rightarrow$ Щеняча, гора $\rightarrow$ Щеняче, сл. [Хр Куп, ХГ СНМ, с. 109], Щенячий, х. [Хр Швч, АТП-46,

12. Топоніми, марковані ознаками наявності або відсутності води або вологи в річці чи на місцевості. Така семантична система представлена відповідними одиницями:

- 'значна зволоженість місиевості' $\rightarrow$ Мокрянка, б. $\rightarrow$ Мокрянка, с. [Хр Кргр, АТП-46, с. 603], Грузьке, ур. $\rightarrow$ Грузький, х. [Хр Охт, ХГ СНМ, с. 28], Грузький, яр $\rightarrow$ Грузький, х. [Вр Брч, ВГ СНМ, с. 23];

- 'наявність води' $\rightarrow$ Водяне, ур. $\rightarrow$ Водяний, х. [Хр Влк, ХГ СНМ, с. 47];

- 'повноводність' / ‘багатоводність' $\rightarrow$ Водяна, р. $\rightarrow$ Водяний, х. [Хр Куп, ХГ СНМ, с. 117], Мокра Розсош, р. $\rightarrow$ Мокра Розсош, х. [Вр Остр, ВГ СНМ, с. 120], Багата, р. $\rightarrow$ Багата, с. [Плт Кнгр, ПГ СНМ, с. 102], Повна, р. $\rightarrow$ Повне, с. [Хр Ввч, ТКХО];

- 'неповноводність' / 'маловодність' $\rightarrow$ Суха Кам'янка, р. $\rightarrow$ Суха Кам'янка, с. [Хр Із, ХГ СНМ, с. 88], Суха Казинка, р. $\rightarrow$ Суха Казинка, сл. [Вр Вал, ВГ СНМ, с. 56], Сухий Мерчик, р. $\rightarrow$ Сухий Мерчик, х. [Хр Бгд, ХГ СНM, c. 41].

Отже, природні ознаки географічних одиниць відіграють важливу роль у продукуванні лексики різних топонімних класів. Найбільшу їх кількість виявлено у групі назв із семемою 'рослини'. Досить повними є ряди топонімів із «тваринною» семантикою, а також із семемами на позначення кольору об'єкта та геофізичних параметрів денотата. Незначна частина таких лексичних одиниць стала наслідком передачі ознак істот, причому уособлення найчастіше виявляється в гідронімному пласті ономастичної лексики. Реалізація такого прийому зумовлена дією двох процесів - онімізації та антропоморфізації.

У подальшому планується аналогічне дослідження назв природних географічних одиниць на суміжній із Слобожанщиною території і здійснення порівняльного аналізу на рівні статистики.

a) першоджерела

\section{Умовні скорочення}

АСУГ-ПАхтУ - План Ахтырского уезда // Атлас Слободской украинской губернии, сочинён по разделений оной вновь на десять уездов в 1802 году.

АСУГ-ПВлчУ - План Волчанского уезда // Атлас Слободской украинской губернии, сочинён по разделений оной вновь на десять уездов в 1802 году.

АСУГ-ПИзУ - План Изюмского уезда // Атлас Слободской украинской губернии, сочинён по разделений оной вновь на десять уездов в 1802 году.

АТД-59 - Воронежская область: административно-территориальное деление на 1 апреля 1959 года. Воронеж : Книжное изд-во, 1959. - 251 с.

АТП-46 - Українська РСР: адміністративно-територіальний поділ на 1 вересня 1946 р. / відп. ред. М. Ф. Попівський. - К. : Укр. вид-во політ. літ-ри, 1947. - Вид. 1. - 1064 с.

АТП-67 - Українська РСР: адміністративно-територіальний поділ на 1 квітня 1967 р. (3 додатком відомостей про зміни до 1 січня 1969 року) : у 2-х т. - К. : Вид-во політ. літ-ри України, 1969. - Т. 1. - 540 с.

АТП-72 - Українська РСР: адміністративно-територіальний поділ на 1 січня 1972 року (3 додатком відомостей про зміни до 1 травня 1973 року) / упор. Д. О. Шелягін ; відп. ред. В. І. Кирненко. - К. : Вид-во політ. літ-ри України, 1973. - 815 с.

АТУ-87 - Українська РСР: адміністративно-територіальний устрій на 1 січня 1987 року. - К. : Головна редакція УРЕ, 1987. - 504 с.

АХН-КХрУ - Карта Харьковского уезда // Атлас Харьковского Наместничества 1787 г. с топографическим описанием. Посвящается Археологическому Съезду : Издание Харьковского губернского статистического комитета под ред. В. В. Иванова. - Харьков, 1902. 
АХН-КХтмУ - Карта Хотмыжского уезда // Атлас Харьковского Наместничества 1787 г. с топографическим описанием. Посвящается Археологическому Съезду : Издание Харьковского губернского статистического комитета под ред. В. В. Иванова. - Харьков, 1902.

БО АТД - Белгородская область: административно-территориальное деление на 1 января 1959 года. Белгород : Книжное изд-во, 1959. - 155 с.

ВВ3 - Прохоров В. А. Вся Воронежская земля: краткий историко-топонимический словарь. - Воронеж : Центр.-Черноз. книжное изд-во, 1973. - 367 с.

ВГ СНМ - Списки населённых мест Российской империи. Т. IX. Воронежская губерния: список населённых мест по сведениям 1859 года. - СПб. : Издан ЦСК МВД, 1865. - 157 с.

ЖТКХГ - Жизнь и творчество крестьян Харьковской губернии: очерки по этнографии края / под ред.

В. В. Иванова. - Харьков : Типография губернского правления, 1898. - Т. 1. - 1012 с.

ИСОХГ - Пассек В.В. Историко-статистическое описание Харьковской губернии 1836 года // Материалы для статистики Российской империи. - СПб. : В типографии МВД, 1839. - С. 125-167.

ИСОХЕ-3 - Историко-статистическое описание Харьковской епархии: уезды Ахтырский, Богодуховский, Лебединский и Сумской. - М. : Типография Готье, 1857. - Отд. 3. - С. 336-603.

ИСОХЕ-4 - Историко-статистическое описание Харьковской епархии: уезды Змиевский и Волчанский. Харьков : В Университетской типографии, 1857. - Отд. 4. - 336 с.

ИСОХЕ-5 - Историко-статистическое описание Харьковской епархии: Изюмский, Купянский и Старобельский уезды. Купянский и Старобельский округи военного поселения. - Харьков : В Университетской типографии, 1858. - Отд. 5. - 461 с.

ІМСУ ХО - Харківська область // Історія міст і сіл УРСР : в 26-и т. - К. : УРЕ АН УРСР, 1967. - 1002 с.

КВУ - Карта Волчанского уезда / сост. А. Ф. Шелеспанов. - М 1:126 000. Харьков, (Б. г.).

КГ СНМ - Списки населённых мест Российской империи. Т. ХХ. Курская губерния: список населённых мест по сведениям 1862 года - СПб. : Издан ЦСК МВД, 1868. - 206 с.

КСП : ХС-9 - Карта Слободских полков на 1764 год // Харьковский сборник: литературно-научное приложение к «Харьковскому календарю» на 1895 г. / под ред. В.В. Иванова. - Харьков : Типография губернского правления, 1895. - Вып. 9. - 494 с.

КСУГ-РА - Карта Слободской Украинской Губернии (карта № 36) // Российский атлас из 43 карт состоящий и на 41 губернию Империю разделяющий: Издан при Географическом департаменте, 1800 г.

НМВГ-28 - Населённые места Воронежской губернии: систематический перечень и алфавитный указатель к карте Воронежской губернии с приложением окружного и районного распределения населённых мест по данным на 23 мая 1928 г. - Воронеж : Издание Воронежского губстатотдела, 1928. - 190 с.

ОИКСОМГ - Багалей Д. И. Очерки из истории колонизации степной окраины Московского государства /

Д. И. Багалей. - М. : В Университетской типографии, 1887. - 614 с.

ОХН - Описи Харківського намісництва кінця XVIII ст.: описово-статистичні джерела / АН УРСР. Археограф. комісія та ін. Упоряд.: В. О. Пірко, О. І. Гурій. - К. : Наук. думка, 1991. - 221 с.

ПГ СНМ - Списки населённых мест Российской империи. Т. ХХXIII. Полтавская губерния: список населённых мест по сведениям 1859 года. - СПб. : Издан ЦСК МВД, 1862. - 262 с.

ПИПН - Предварительные итоги переписи населения 1926 года по Купянскому округу. - Купянск:

Типография «Советская печать», 1927. - 55 с.

ПКРИ - Подробная карта Российской империи и близ лежащих заграничных владений. Сочинена, гравирована и печатана при... депо карт, СПб., (б. г.), 129 карт.

ПКХГ - Памятная книжка Харьковской губернии на 1865 год / сост. Я. Голяховский. - Харьков :

В Университетской типографии, 1865. - 393 с.

Р. ПГОНО

СВСХГ - Список волостей и селений Харьковской губернии. - Харьков : Типография «Печатное дело», 1909. $-56 \mathrm{c}$.

СЗПКО - Список заселених пунктів Куп’янської округи 1925 року. - Куп’янськ : Друкарня «Червоний друк», 1926. - 57 с.

СЗПСТХО - Список залюднених пунктів і сільрад на території Харківської округи. - Харків : «ХарківДрук», 1927. - 110 с.

СКХЕ - Справочная книга для Харьковской епархии / сост. И. Самойлович. - Харьков : Типолитография

И. М. Варшавчика, 1904. - 471 с.

СНПАО - Список населённых пунктов Артёмовского округа по данным переписи 1926 г. - Артёмовск :

Типография изд-ва «Украинский рабочий». - 1927. - 56 с.

СНПЛО - Список населённых пунктов Луганского округа. Составлен по материалам переписи

17 декабря 1926 года. - Луганск : Друкарня вид-ва «Луганська правда», 1927. - 148 с.

ССОВХГ - Список сельских общин и волостей на территории Харьковской губернии. - Харьков :

Типография М. Гордона, 1876. - 112 с.

СССВГ. ПУ - Сборник статистических сведений по Воронежской губернии. Павловский уезд. Воронеж : Типография В. И. Исаева, 1891. - Т. 7. - Вып. 1. - 166 с. 


\section{РОЗДІЛ VІ. ЛІНГВОГЕОГРАФІЯ, СОЦІОЛІНГВІСТИКА, ОНОМАСТИКА Й ТЕРМІНОЛОГІЯ: АКТУАЛЬНІ ПІДХОДИ, КАТЕГОРІЇ ТА АСПЕКТИ}

СССВГ. БгчУ - Сборник статистических сведений по Воронежской губернии. Богучарский уезд. Воронеж : Типография В. И. Исаева, 1890. - Т. 8. - Вып. 1. - 351 с.

СССКГ. ГУ - Сборник статистических сведений по Курской губернии : Грайворонский уезд. - Курск : Типография Курского губернского земства, 1885. - Вып. 9. - 324 с.

ТКХБО - Харьковская и Белгородская области: обзорно-топографические карты территорий Украины и сопредельных государств. - Харьков : СПАЭРО плюс, фактор ЛТД, 1996. - Вып. 1. - М 1:200 000.

ТКХО - Харьковская область: [топографічна карта]. - К. : ВКФ ТСВС Украины, 1997. - М 1:200 000.

ХГ СНМ - Списки населённых мест Российской империи. Т. XLVI. Харьковская губерния: список населённых мест по сведениям 1864 года. - СПб. : Издан ЦСК МВД, 1869. - 210 с.

ХО. АТП-59 - Харківська область: адміністративно-територіальний поділ на 1 грудня 1959 року. Довідник. - Харків : Книжкове вид-во, 1960. - 103 с.

ХО. АТП-67 - Харківська область: адміністративно-територіальний поділ на 1 квітня 1967 року. Харків : Прапор, 1967. - Вид. 2. - 135 с.

ХУ-КС - Харьковский уезд. Карта спорных с Азовской губернией селений Харьковского и Изюмского уездов Слободской губернии, находящихся по р. Донцу на Крымской стороне с показанием их угодий. - Б. м., XVIII ст.

ЮЧВГ - Южная часть Воронежской губернии: топографическая карта. - СПб., 1869. - М 1:420 000. Долгота от Пулкова М 10 в. в 1 дм.

б) губернії / області

Бгр - Бєлгородська, Вр - Воронезька, Врш - Ворошиловградська, Дц - Донецька, Кр - Курська. Лг Луганська, Плт - Полтавська, См - Сумська. Хр - Харківська

в) повіти / райони

Бгд - Богодухівський, Бгр - Бєлгородський, Бгч - Богучарський, Блвд - Біловодський, Блз Близнюківський, Блк - Балаклійський, Блпл - Білопільський, Бр - Борівський, Брч - Бірючинський, Вал Валуйський, Вбрл - Великобурлуцький, Ввч - Вовчанський, Влк - Валківський, Вртп - Верхньотеплівський, Гдц - Гадяцький, Грв - Грайворонський, Дврч - Дворічанський, Дрг - Дергачівський, Зм - Зміївський, Змл Землянський, Знк - Зіньківський, Із - Ізюмський, Кб - Кабанський, Клч - Калачівський, Кнгр Костянтиноградський, Крлм - Краснолиманський, Крм - Кремінський, Крпл - Краснопільський, Кртк Коротояцький, Крч - Корочанський, Куп - Куп'янський, Лбд - Лебединський, Лзол - ЛозноОлександрівський, Лпц - Липецький, Мик - Микитівський, Млв - Міловський, Мрк - Марківський, Мрф Мерефинський, Нвдл - Нововодолазький, Носк - Новооскільський, Об - Обоянський, Остр - Острогозький, Охт - Охтирський, Пвл - Павлівський, Пдгр - Підгоренський, Пп - Петропавлівський, Рзш - Розсошанський, Св - Сватівський, Свн - Савинський, Сдж - Суджинський, Сл - Слов'янський, См - Сумський, Стлг Станично-Луганський, Стрб - Старобільський, Схн - Сахновщинський, Трс - Тростянецький, Хр Харківський, Хтм - Хотмизький, Чг - Чугуївський, Шбк - Шебекінський, Швч - Шевченківський

г) інші скорочення

б. - балка, верш. - вершина, верш. ур. - вершина урочища, верш. яру - вершина яру, д. - деревня. кол. колодязь, м. - місто, м-ко - містечко, оз. - озеро, прот. - протік, прот. руч. - протік ручая, р. - річка, руч. ручай, с. - село, сел. - селище, Слб. Із. п. - Слобідський Ізюмський полк, Слб. Укр. губ. (Куп) - Слобідська Українська губернія, сл. - слобода, смт - селище міського типу, сц. - сільце, улог. - улоговина, ур. - урочище, х. - хутір

\section{References}

Buchko, D. G. "Printsipyi Nominatsii V Toponimii Ukrainyi.(назва статті англ)". Ukrayinske movoznavstvo (назва журналу англ) 18 (1991): 66-73. Print.

Karpenko, Yu. A. "Toponimyi i geograficheskie termininyi : voprosyi vzaimosvyazi (назва статті англ)" Mestnyie geograficheskie terminyi (назва журналу англ) 81 (1970): 36-46. Print.

Nikonov, V. A. "Vvedenie V Toponimiku (назва англ)". (1965): 180. Print.

Otin, E. S. "K etimologii nazvaniy nekotoryih rek «animalistskogo» proishozhdeniya (назва англ)". Povidomlennya ukrayinskoyi onomastichnoyi komisiyi (назва журналу англ) 2 (1967): 13-27. Print.

Otin, E. S. "Gidronimi shidnoyi Ukrayini (назва англ)". (1977). 156. Print.

Feoktistova, I. E. "K voprosu o peyorativah (назва англ)". Voprosyi onomastiki (назва англ). 13 (1979): 79-86. Print.

Надійшла до редакції 25 березня 2018 року

\section{SIGNS OF DENOTATE AS THE MOTIVE OF THE NOMINATION OF THE CORRELATIVE NAME (WITHIN THE AREA OF SLOBOZHANSHCHYNA) \\ Tamara Lukianchuk}

Department of General and Applied Linguistics and Slavonic Philology, Donetsk National University named after Vasyl Stus, Vinnytsia, Ukraine 


\begin{abstract}
Background. The study of onomastic vocabulary in terms of the motivation of its creation on the basis of natural attributes is not investigated dentally. This article is devoted to this issue.

Purpose. Representation of internal and external features, laid in the basis toponymic nomination on the level of names of natural geographical objects.

Results. In this article we have investigated the features of the creation of the names of natural geographical objects: rivers, lakes, girders, basins, ravines, which became generative for oikonimnyh tokens and which were established according to the results of the study of the source base of the nineteenth and twentieth centuries. The investigated material was grouped according to the lexical-semantic series with names, motivated by certain features, based on the toponym nomination. At the same time, the main thing for hydronyms is the nature of the noises created by the water, the speed of the flow in the river, its taste and color, as well as the smell and temperature. For other layers of toponymic vocabulary, an important factor in creation is the "floristic" semantics, which indicates the presence or absence of vegetation elements, etc. In addition, amongst the external features the determinant ones are the features of the shape of the object, its geophysical parameters and features related to the surrounding fauna. Toponims that were marked by the presence or absence of water or moisture in the river or in the area were also identified. A number of toponyms with semas are sufficiently complete to indicate the color of the object.

Discussion. To conclude, the natural features of geographic units play an important role in the production of vocabulary of various toponym classes. In the future, we plan a similar study of the names of natural geographical units in the territory adjacent to the Slobozhanshchyna, as well as carrying out a comparative analysis at the level of statistics.

Key words: hydronym, oikosm, toponym nomination, pejorative, semantics.

Vitae

Tamara Lukianchuk is senior lecturer of Department of General and Applied Linguistics and Slavonic Philology at Donetsk National University named after Vasyl Stus. Her areas of research interests include functional linguistics, cognitive linguistics, text linguistics.

Correspondence: bugovoe@gmail.com
\end{abstract}

